\title{
The Cloning of Chromosomal DNA Associated with Methicillin and Other Resistances in Staphylococcus aureus
}

\author{
By P. R. MATTHEWS, ${ }^{*}$ K. C. REED AND P. R. STEWART \\ Department of Biochemistry, Faculty of Science, Australian National University, Canberra, \\ ACT 2601, Australia
}

(Received 15 October 1986; revised 6 February 1987)

Competitive hybridization was used to detect the deletion of chromosomal DNA accompanying the loss of resistance to methicillin (and concomitantly, to cadmium, mercury and tetracycline) from a clinical strain of methicillin-resistant Staphylococcus aureus (MRSA). The method was also used to screen a partial plasmid library of chromosomal $H$ indIII fragments from the MRSA strain. Eight recombinant plasmid clones were identified as containing DNA included in the deletion. These clones were used as probes to screen a phage library of the total DNA of the same MRSA strain, resulting in the isolation of overlapping recombinant phage clones carrying $24 \mathrm{~kb}$ of the deleted DNA. Two of the cloned HindIII fragments were associated closely with methicillin resistance, as shown by probing DNA from an independent methicillinsensitive/resistant transduced strain pair and from two MRSA strains following growth in the presence of high concentrations of methicillin. The endonuclease map of the cloned DNA indicates the presence of four copies of a direct repeat less than $1 \mathrm{~kb}$ in size. The map is also consistent with the presence in the chromosome of sequences for mercury resistance (mer $A$ mer $B$ ) and for the tetracycline-resistance plasmid pT181.

\section{INTRODUCTION}

Methicillin resistance among strains of Staphylococcus aureus has presented a clinical problem dating from shortly after introduction of the drug in the early $1960 \mathrm{~s}$. Despite numerous studies of the phenomenon and efforts to determine the mechanism of resistance, the precise nature of the genetic determinant of methicillin resistance ( $\mathrm{mec}$ ) remains unknown. Genetic evidence for its probable location on a transposable element was presented by Stewart \& Rosenblum (1980), who showed that no allelic equivalent of mec exists in sensitive strains. This possibility has been further strengthened by the recent work of Reynolds \& Fuller (1986), who showed the presence of an additional penicillin-binding protein (PBP) in four independently isolated methicillinresistant $S$. aureus (MRSA) strains. This protein not only showed a much lower affinity for penicillin than the other three PBPs present in $S$. aureus, but yielded different penicillinpeptides on partial proteolysis of the penicillin-PBP complex, implying that a different protein and hence a new and different gene is present in methicillin-resistant strains.

In attempting to clone the mec gene, the use of simple 'shotgun' cloning techniques was precluded by the difficulty and low efficiency of $S$. aureus transformation systems, and the possibility that more than a single genetic locus is involved (Berger-Bachi \& Kohler, 1983). We decided instead to utilize the generation of an isogenic methicillin resistant/sensitive strain pair by the acriflavine 'curing' of methicillin resistance from a clinical MRSA strain. As acriflavine is known to cause loss of genetic markers by deletion of DNA, we first showed that this had indeed occurred concomitantly with the loss of methicillin resistance, and then cloned and

Abbreviations: MRSA, methicillin-resistant Staphylococcus aureus; PBP, penicillin-binding protein. 
mapped $24 \mathrm{~kb}$ of the DNA deleted. Fragments of the cloned DNA were subsequently used to probe total DNA from two clinical MRSA isolates grown in both high and low concentrations of methicillin, and from an isogenic strain pair one of which had been transduced to methicillin resistance (Cohen \& Sweeney, 1970).

\section{METHODS}

Bacterial strains, plasmids and phages. The bacterial strains used and their relevant characteristics are given in Table 1. The plasmids used and constructed are given in Table 2. Strains ANS46(1000) and C5(1000) are variants of ANS46 and C5, step-selected to elevated resistance by prolonged growth in increasing concentrations of methicillin. This was performed by sequential $1: 100$ subculture in $3 \mathrm{ml}$ fresh broth daily, during which the methicillin concentration was steadily increased to $1.2-1.5 \mathrm{mg} \mathrm{ml}^{-1}$ and maintained at that level. Strain C5 took 14 subculturings, or approximately 90 generations, to become sufficiently resistant to grow stably in $1.2 \mathrm{mg}$ methicillin $\mathrm{ml}^{-1}$; it would grow only erratically at higher concentrations. Strain ANS46 took 12 subculturings to grow stably in $1.5 \mathrm{mg}$ methicillin $\mathrm{ml}^{-1}$. Both strains were maintained with daily subculturing at these antibiotic concentrations for the rest of a $40 \mathrm{~d}$ period (approximately 21 subculturings or 140 generations) before the broth cultures were streaked to obtain single colonies on plates containing $1 \mathrm{mg}$ methicillin $\mathrm{ml}^{-1}$. Growth of the step-selected strains was slower than their non-selected counterparts, both on drug-free and on $1 \mathrm{mg}$ methicillin $\mathrm{ml}^{-1}$ agar media. Ten colonies were suspended in $3 \mathrm{ml}$ broth and used to check mannitol fermentation on salt-supplemented agar medium. The cell suspensions were also used to inoculate (with $0.8 \mathrm{ml}) 80 \mathrm{ml}$ broth cultures containing $1 \mathrm{mg}$ methicillin $\mathrm{ml}^{-1}$, which were then incubated with shaking at $37^{\circ} \mathrm{C}$ for $24 \mathrm{~h}$, the cells harvested, and total DNA prepared.

Acriflavine treatment of $S$. aureus cells. Cells were grown in Luria (L) broth with $0.2 \%(w / v)$ glucose (LG) for $5-$ $6 \mathrm{~h}$, and $50 \mu \mathrm{l}$ of this was used to inoculate $5 \mathrm{ml}$ broth containing $12.5,25$ or $50 \mu \mathrm{g}$ acriflavine $\mathrm{ml}^{-1}$. After $2 \mathrm{~d}$ growth at $37^{\circ} \mathrm{C}$ in the dark, the tube showing the least visible turbidity was plated on LG agar at suitable dilutions to give $30-50$ colonies per plate after overnight incubation at $37^{\circ} \mathrm{C}$. These colonies were then replicated using velveteen pads to plates with LG and LG plus $25 \mu \mathrm{g}$ methicillin $\mathrm{ml}^{-1}$. After $48 \mathrm{~h}$ incubation at $37^{\circ} \mathrm{C}$ the plates were compared to detect colonies sensitive to methicillin.

Preparation of total cell DNA. An overnight, shaken culture $\left(37^{\circ} \mathrm{C}\right)$ in $20 \mathrm{ml} \mathrm{LG}$ broth (supplemented with $20 \mathrm{mM}$-Tris/ $\mathrm{HCl} \mathrm{pH} \mathrm{7.5)} \mathrm{was} \mathrm{centrifuged} \mathrm{for} 3 \mathrm{~min}$ at $12000 \mathrm{~g}$ and the pellet washed twice in $10 \mathrm{ml}$ TES (30 mMTris/ $\mathrm{HCl}$ pH 7.8, $50 \mathrm{~mm}-\mathrm{NaCl}, 5 \mathrm{~mm}-\mathrm{EDTA}$ ) before resuspending in $2.5 \mathrm{ml}$ TES plus $2.5 \mathrm{M}-\mathrm{NaCl}$. Lysostaphin was added to $30 \mu \mathrm{g} \mathrm{ml}^{-1}$ and the solution incubated for $1 \mathrm{~h}$ at $37^{\circ} \mathrm{C}$. At this time $0.75 \mathrm{ml} 10 \%(\mathrm{w} / \mathrm{v})$ Sarkosyl and $0.63 \mathrm{ml} 0.5 \mathrm{M}$-EDTA were added and the lysed suspension was incubated at $65^{\circ} \mathrm{C}$ for $20 \mathrm{~min}$. One $\mathrm{ml} \mathrm{TE} \mathrm{buffer}$ (10 mM-Tris/HCl pH 8.0, $1 \mathrm{~mm}$-EDTA) and $4.8 \mathrm{ml}$ Tris-equilibrated phenol (Maniatis et al., 1982) were then added, and the mixture was shaken gently at room temperature for $10 \mathrm{~min}$. The phases were broken by centrifuging at $27000 \mathrm{~g}$ for $15 \mathrm{~min}$; the upper phase was decanted and the phenol phase re-extracted with $4 \mathrm{ml} \mathrm{TE}$. The two aqueous phases were then combined with $18 \mathrm{ml}$ cold ethanol and inverted gently to mix. Precipitated nucleic acid was collected on a spatula, rinsed thoroughly in $70 \%(\mathrm{v} / \mathrm{v})$ ethanol, dried and dissolved in $0.5 \mathrm{ml}$ TE by gentle repeated inversion overnight at $4^{\circ} \mathrm{C}$. DNAase-free RNAase was then added to $50 \mu \mathrm{g} \mathrm{ml}^{-1}$ and the solution incubated at $37^{\circ} \mathrm{C}$ for $30 \mathrm{~min}$ before layering onto $3.8 \mathrm{ml} 1 \mathrm{M}-\mathrm{NaCl}, 20 \mathrm{mM}-\mathrm{Tris} / \mathrm{HCl} \mathrm{pH} 8.0$ and centrifuging in a Beckman SW60 rotor at $20^{\circ} \mathrm{C}$ for $2 \mathrm{~h}$ at 58000 r.p.m. After draining and drying the tube walls, the pelleted DNA was dissolved in $0.5 \mathrm{ml} \mathrm{TE}$ by repeated inversion overnight at $4^{\circ} \mathrm{C}$. The yield was $0.2-0.6 \mathrm{mg}$ high-molecular-mass DNA, with an $A_{260}: A_{280}$ ratio of approximately 1.8 .

Preparation of bacteriophage DNA. The following procedure was used for the rapid purification of recombinant phage DNA; it is a combination and adaptation of a number of methods. Purification of Charon 30 phage DNA for construction of the library was according to the large-scale preparation of Maniatis et al. (1982).

Host cells were prepared by growing an overnight culture of LE392 cells in well-aerated L broth supplemented with $0.2 \%$ maltose (Maniatis et al., 1982). The cells were chilled, pelleted at $750 \mathrm{~g}$ for $10 \mathrm{~min}$ and gently resuspended in $10 \mathrm{mM}-\mathrm{MgCl}_{2}$ (one-half the volume of the original culture).

The optimal number of host cells and phage used for inoculation varied greatly with the virulence of the recombinant phages. Generally, phage producing small plaques required adsorption at a high ratio of phage to cells, while the reverse was true for phage which produced large plaques. The small-plaque-producing recombinants found in this study were adsorbed by mixing $2-5 \times 10^{7}$ p.f.u. of phage with $1-3 \times 10^{8}$ cells $(20 \mu \mathrm{l}$ of cell suspension), allowing the mixture to stand at room temperature for $20-30 \mathrm{~min}$, adding the suspension to $50 \mathrm{ml}$ fresh, pre-warmed NZCYM medium (Maniatis et al., 1982) and incubating with good aeration at $37^{\circ} \mathrm{C}$. For largeplaque-forming recombinants the number of phage particles was reduced 2-3-fold and the number of cells increased by a similar factor.

Good phage yields coincided with lysis after 6-10 h, as the cells were entering stationary phase. Cultures which did not lyse could often be rescued by inoculating a fresh $50 \mathrm{ml}$ of NZCYM with 1 or $2 \mathrm{ml}$ of the unlysed culture and re-incubating. 
Table 1. Bacterial strains

Strain

ANS46

$\begin{array}{ll}\text { ANS62 } & \mathrm{Mc}^{S} \mathrm{Km}^{R} \mathrm{Tc}^{\mathrm{S}} \mathrm{Hg}^{\mathrm{S}} \mathrm{Cd}^{\mathrm{S}} \mathrm{Nv}^{\mathrm{S}} \mathrm{Cm}^{\mathrm{R}} \mathrm{Er}^{\mathrm{R}} \\ \mathrm{T} 5 & \mathrm{Tm}^{\mathrm{R}} \mathrm{Sm}^{\mathrm{R}} \\ \mathrm{Mc}^{\mathrm{R}} \mathrm{Km}^{\mathrm{S}} \mathrm{Tc}^{\mathrm{S}} \mathrm{Hg}^{\mathrm{R}} \mathrm{Cd}^{\mathrm{R}} \mathrm{Nv}^{\mathrm{S}} \mathrm{Tm}^{\mathrm{S}}\end{array}$

$\mathrm{SC} 4$

SC4mec

$\begin{array}{ll}\text { ANS46(1000) } & \text { As for ANS46 with } \mathrm{Mc}^{\mathrm{R}} \text { step-selected to } \\ \text { higher level } \\ \text { As for C5 with } \mathrm{Mc}^{\mathrm{R}} \text { step-selected to } \\ \text { higher level; } \mathrm{Hg}^{\mathrm{S}} \mathrm{Cd}^{\mathrm{S}} \text { due to loss of } \\ \text { pIC5 }\end{array}$

Phenotype ${ }^{*} /$ genotype

$\mathrm{Mc}^{R} \mathrm{Km}^{R} \mathrm{Tc}^{\mathrm{R}} \mathrm{Hg}^{R} \mathrm{Cd}^{R} \mathrm{Nv}^{\mathrm{S}} \mathrm{Cm}^{\mathrm{R}} \mathrm{Er}^{\mathrm{R}}$
$\mathrm{Tm}^{R} \mathrm{Sm}^{\mathrm{R}}$
- Mc, methicillin; Km, kanamycin; Tc, tetracycline; Hg, mercuric ions, Cd, cadmium ions; Nv, novobiocin; $\mathrm{Cm}$, chloramphenicol; Er, erythromycin; Tm, trimethoprim; $\mathrm{Sm}$, streptomycin.
Clinical isolate from K. Harvey, Royal Melbourne Hospital, Victoria, Australia, 1982 [also described as RM4 (Heneine \& Stewart, 1986)]

Prepared from ANS46 by acriflavine treatment (this study)

From S. Cohen, Michael Reese Hospital, Chicago, USA; originally isolated in Seattle, USA, 1967

From S. Cohen, Chicago, USA

From S. Cohen, Chicago, USA (mec from

This study

This study
C5 transduced by phage $\phi 80$ to SC4)

\section{Table 2. Plasmids and phages}

Plasmid or phage

pUC9

pMAl, 2, 3, 4, 5, 6, 7, 8

pMF1, 2, 3, 4, 5

Charon 30

$\phi \mathrm{ChMl,2,3}$

pI524

pIC5

pWDB2
Description

E. coli cloning plasmid (Vieira \& Messing, 1982)

HindIII fragments of ANS46 DNA inserted into pUC9 (Fig. 2)

Endonuclease fragments from recombinants of Charon 30 phage inserted into appropriate site of pUC9 (Fig. 2)

Lambda cloning phage (Rimm et al., 1980)

Recombinants of Charon 30 carrying Sau3A fragments from ANS46 inserted into BamHI site of phage

$S$. aureus penicillinase plasmid carrying multiple resistance determinants (Shalita et al., 1980)

Penicillinase plasmid from $\mathrm{C} 5$ carrying multiple resistance determinants (Cohen \& Sweeney, 1970)

From B. Berger-Bachi and W. Beck, Zurich, Switzerland; recombinant plasmid containing $E$. coli vector and $S$. aureus chromosomal DNA associated with methicillin resistance (Beck et al., 1986)

After lysis, 10 drops of chloroform and $10 \mu$ leach of stocks of DNAase (10 $\left.\mathrm{mg} \mathrm{ml}^{-1}\right)$ and RNAase $\left(10 \mathrm{mg} \mathrm{ml}^{-1}\right)$ were added, and incubation was continued for $1 \mathrm{~h}$ at $37^{\circ} \mathrm{C}$. Forty $\mathrm{ml}$ of the culture was then chilled, centrifuged at $17000 \mathrm{~g}$ for $10 \mathrm{~min}$ at $4^{\circ} \mathrm{C}$ to remove cell debris and the supernatant decanted directly into a centrifuge tube. After centrifuging for $1 \mathrm{~h}$ at 27000 r.p.m. and $4^{\circ} \mathrm{C}$ in a Beckman SW28 rotor, the supernatant was decanted and the phage pellet resuspended in $2 \mathrm{ml} \mathrm{SM}$ buffer (Maniatis et al., 1982) by aspiration with a Pasteur pipette. To this was added $50 \mu 120 \%(\mathrm{w} / \mathrm{v})$ SDS, $80 \mu 10.5 \mathrm{M}$-EDTA and $10 \mu \mathrm{l} 10 \mathrm{mg}$ proteinase $\mathrm{K} \mathrm{ml}^{-1}$, followed by incubation for $\mathrm{I} \mathrm{h}$ at $60^{\circ} \mathrm{C}$ with occasional aspiration to break up any remaining clumps.

The suspension was then extracted twice with equal volumes of phenol, once with chloroform/iso-amyl alcohol $(24: 1, \mathrm{v} / \mathrm{v})$ and several times with butan-1-ol to concentrate it to approx. $0.8 \mathrm{ml}$. This was layered onto $3.5 \mathrm{ml} 1 \mathrm{M}$ $\mathrm{NaCl}, 20 \mathrm{~mm}-\mathrm{Tris} / \mathrm{HCl} \mathrm{pH} 8.0$ and centrifuged in a Beckman SW60 rotor at $20^{\circ} \mathrm{C}$ for $2 \mathrm{~h}$ at 58000 r.p.m. The supernatant was discarded, the tube walls were swabbed and dried, and the DNA pellet was resuspended in $200 \mu \mathrm{l}$ TE with gentle shaking and warming. The yield of DNA ranged from 20 to $200 \mu \mathrm{g}$ depending on plaque-size of phage and extent of broth lysis. The DNA was susceptible to restriction endonucleases although sometimes contaminated with small amounts of RNA.

Preparation of plasmid DNA. Plasmid DNA was prepared by both small- and large-scale alkaline lysis procedures (Maniatis et al., 1982), with lysostaphin $\left(1 \mathrm{mg} \mathrm{ml}^{-1}\right)$ added for $S$. aureus suspensions. Large-scale preparations were further purified, where necessary, by caesium chloride/ethidium bromide density gradient ultracentrifugation. 
Phage cloning. Charon 30 arms cut with BamHI and lambda phage packaging extracts were prepared as described by Maniatis et al. (1982). Total DNA from strain ANS46 was partially cut with Sau3A and digested with calf intestinal alkaline phosphatase in $0.5 \%$ SDS, $100 \mathrm{~mm}$-Tris $\mathrm{pH} 9.0$ at $37{ }^{\circ} \mathrm{C}$ for $1 \mathrm{~h}$. After extraction with phenol/chloroform, and ethanol precipitation, the DNA was fractionated on a $5-25 \% \mathrm{NaCl}$ gradient (SW 41 rotor, 37000 r.p.m., $4.5 \mathrm{~h}, 25^{\circ} \mathrm{C}$ ) and fractions containing DNA in the $12-18 \mathrm{~kb}$ size range were identified by agarose gel electrophoresis after removing salt by dialysis. DNA from these fractions was mixed with the Charon 30 arms preparation at a vector/insert molar ratio of approximately $2: 1$, and ligated using T4 DNA ligase (Pharmacia PL) as described by Nilsson \& Magnusson (1982), then packaged and the recombinant phage assayed by plating (Maniatis et al., 1982).

Plasmid cloning. Both the plasmid library and plasmid sub-cloning utilized the vector pUC9 cut with appropriate restriction endonuclease(s), treated as described above with calf intestinal alkaline phosphatase, and further purified either on a sucrose gradient or agarose gel, to remove trace amounts of uncleaved plasmid. DNA was extracted from gels either by electro-elution or melting (Maniatis et al., 1982). Insert DNA for the plasmid library was isolated from a phenol-extracted, ethanol-precipitated HindIII digest of ANS46 total cell DNA by fractionation on a 5-25\% sucrose gradient (SW41 rotor, 36000 r.p.m., 24 h, $4{ }^{\circ} \mathrm{C}$ ), and subsequent identification of fractions containing $1.5-3.5 \mathrm{~kb}$ fragments by gel electrophoresis. Ligation of insert fragments to vector DNA was carried out at a vector:insert molar ratio of approximately 5:1 and a DNA concentration of approximately $1 \mu \mathrm{g} \mathrm{ml}^{-1}$ for the plasmid library, and at a ratio of approximately $1: 1$ at $5 \mu \mathrm{g} \mathrm{ml}^{-1}$ for sub-cloning (Nilsson \& Magnusson, 1982).

Filter hybridization. S. aureus chromosomal DNA, and recombinant phage and plasmid DNA, were cut with restriction endonucleases according to the supplier's (Pharmacia PL) instructions, and transferred from horizontal agarose gels to nitrocellulose by the method of Southern (1975) or to Zeta Probe (Bio-Rad) by the method of Reed \& Mann (1985). Recombinant plasmid clones were replicated from 96-well microtitre plate cultures to nitrocellulose filters on $2 \mathrm{YT}$ agar (Maniatis $e$ t al., 1982) with $50 \mu \mathrm{g}$ ampicillin $\mathrm{ml}^{-1}$, and incubated for $6 \mathrm{~h}$ at $37^{\circ} \mathrm{C}$; the filters were then transferred to $\mathrm{L}$ agar containing $50 \mu \mathrm{g}$ penicillin $\mathrm{ml}^{-1}$ and $10 \mu \mathrm{g}$ chloramphenicol $\mathrm{ml}^{-1}$, and incubated at $37^{\circ} \mathrm{C}$ overnight. Subsequent lysis and binding of bacterial DNA to the filters, as with the adsorption, lysis and binding of bacteriophage DNA to nitrocellulose, was by standard methods (Maniatis et al., 1982).

Filters derived from agarose gels, bacterial colonies or coliphage plaques were hybridized according to the method of Johnson et al. (1984) at $65^{\circ} \mathrm{C}$ in aqueous solution or at $42^{\circ} \mathrm{C}$ with the addition of $50 \%(\mathrm{v} / \mathrm{v})$ formamide to the hybridization solution. Denatured, sheared salmon sperm DNA $\left(100 \mu \mathrm{g} \mathrm{ml}^{-1}\right)$ was also added, and for hybridization with Zeta Probe filters the SDS and skim milk concentrations were $1 \%(w / v)$ and $0 \cdot 5 \%$ (w/v) respectively. After at least $4 \mathrm{~h}$ pre-hybridization the labelled probe DNA was added. The probe consisted of $0.5 \mu \mathrm{g}$ DNA labelled with [ ${ }^{2}$ P]dCTP (Amersham) by nick translation as described previously (Stewart et al., 1985). For normal (non-competitive) hybridization, the labelled DNA was freed from unincorporated nucleotides by adding $40 \mu \mathrm{g}$ sheared salmon sperm DNA and precipitating with ethanol. After redissolving in $200 \mu \mathrm{l} 0 \cdot 3 \mathrm{M}-\mathrm{NaOH}$, the DNA was heated to $100^{\circ} \mathrm{C}$ for $10 \mathrm{~min}$ to denature and fragment the DNA, neutralized with $10 \mu 11 \mathrm{M}-\mathrm{Tris} / \mathrm{HCl}$ $\mathrm{pH} 7.5$ and $5.5 \mu \mathrm{l}$ concentrated $\mathrm{HCl}$, and added to the hybridization mixture. For competitive hybridization, $0.5 \mu \mathrm{g}$ ANS46 total DNA was labelled, and $100 \mu \mathrm{g}$ ANS62 total DNA was added before precipitation, instead of the salmon sperm DNA. After alkali fragmentation, denaturation and neutralization as described above, the mixture of DNA (in $215 \mu \mathrm{l}$ ) was allowed to anneal for $8 \mathrm{~h}$ at $65^{\circ} \mathrm{C}$ before being added to pre-hybridized filters.

\section{RESULTS}

\section{Curing of methicillin and other resistances with acriflavine}

After growth of the MRSA strain ANS46 in broth containing acriflavine at partially inhibitory concentration, approximately 600 colonies were replicated to agar with and without $25 \mu \mathrm{g}$ methicillin $\mathrm{ml}^{-1}$. One colony was found which did not grow on methicillin, and was designated strain ANS62. Subsequent testing showed that while it did not show sensitivity typical of wild-type sensitive strains, it did show an approximately 50-fold reduction in resistance, placing it on the borderline of the generally accepted level $\left(5-10 \mu \mathrm{g} \mathrm{ml}^{-1}\right)$ for methicillin resistance in $S$. aureus. It was also found to have lost resistance to tetracycline, cadmium ions and mercuric ions (Table 1). Cohen \& Sweeney (1970) have reported the curing of methicillin resistance by acriflavine at a similar frequency to that observed here.

In all other biochemical and physiological tests used, ANS62 was phenotypically identical to ANS46. Thus phage typing, coagulase and DNAase production, and twenty metabolic and biochemical tests used for differentiating $S$. aureus biotypes (API System) gave identical results for the two strains. 
(a)

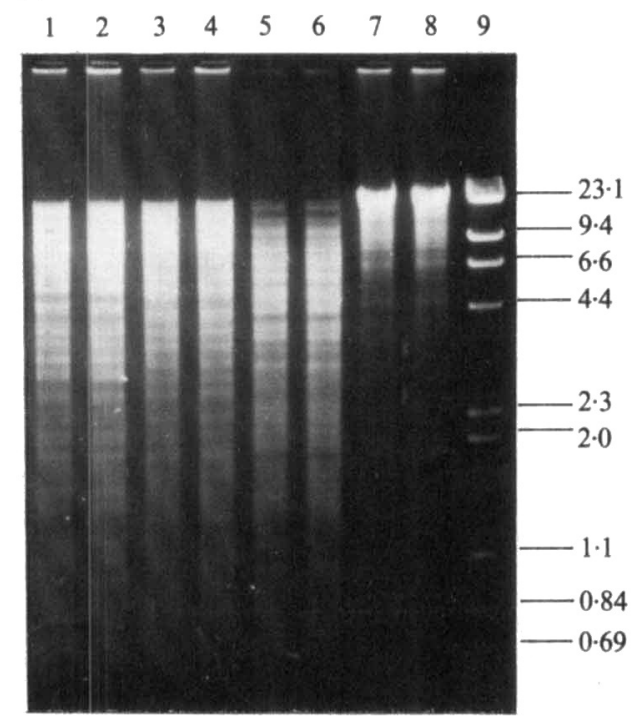

(b)

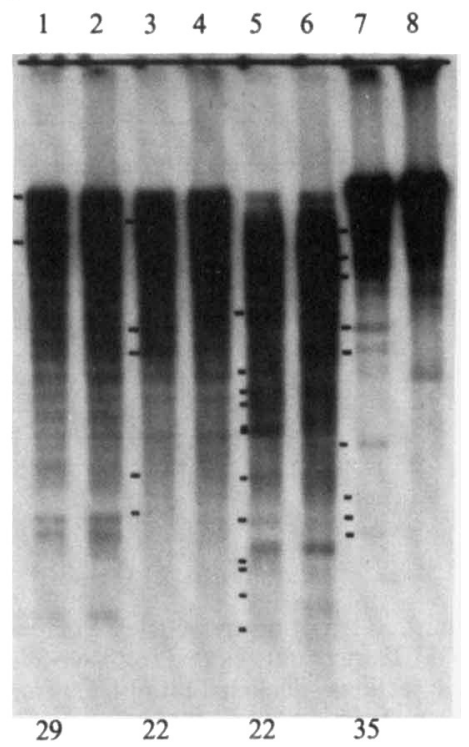

Fig. 1. Detection and sizing of deleted DNA. (a) Agarose gel (1.0\%) electrophoresis of S. aureus total DNA from ANS46 (odd-numbered lanes) and from ANS62 (even-numbered lanes) digested with EcoRI (lanes 1 and 2), Pst I (lanes 3 and 4), HindIII (lanes 5 and 6), and BglII (lanes 7 and 8). Lane 9 contains molecular mass marker fragments ( $\lambda$, HindIII; pUC9, HindIII/DraI) with sizes in kb. (b) Autoradiograph of lanes 1-8 from $(a)$ after transfer to nitrocellulose and competitive hybridization to ${ }^{32}$ P-labelled ANS46 total DNA pre-annealed to unlabelled ANS62 total DNA as described. The totals of the molecular masses of ANS46-specific fragments (marked) are given (in kb) below each oddnumbered lane.

Both ANS46 and ANS62 contain a small plasmid (approx. $3 \mathrm{~kb}$ ), which on the basis of comparison with plasmids found in Australian strains (Gillespie et al., 1984), probably encodes chloramphenicol resistance.

\section{Detection of deletion of chromosomal DNA}

Fig. 1(b) shows the result of competitive hybridization of ANS46/62 total DNA to endonuclease digests of ANS46 and ANS62 DNA separately. Bands hybridizing more strongly in the ANS46 digests represent DNA present in that strain only. The sum of the estimated molecular masses of these bands for each digest is given below each lane, indicating that the total amount of DNA deleted from strain ANS46 is approximately $35 \mathrm{~kb}$. The concentration of deletion fragments in the $1.5-3.5 \mathrm{~kb}$ region of the HindIII digest was the rationale for the construction of a partial plasmid library using HindIII fragments with this size range.

\section{Screening of plasmid library}

Recombinant plasmid transformants were replicated to duplicate nitrocellulose filters and probed as described, except that the second (control) filter was probed with labelled ANS46 total DNA pre-hybridized with an excess of unlabelled ANS46 (instead of ANS62) DNA. Clones showing stronger hybridization when probed with labelled ANS46 DNA which had been prehybridized with unlabelled ANS62 DNA were chosen for further analysis. Of some 800 transformants screened initially, approximately 40 showed enhanced hybridization of probe. Plasmid DNA was prepared from 21 of these, digested with HindIII and the insert and vector fragments separated on duplicate agarose gels. After transfer to nitrocellulose, these were probed with labelled ANS46 and ANS62 total DNA. Insert DNA from only one of the clones showed hybridization with ANS62 DNA, whereas all hybridized to ANS46 DNA. Vector 

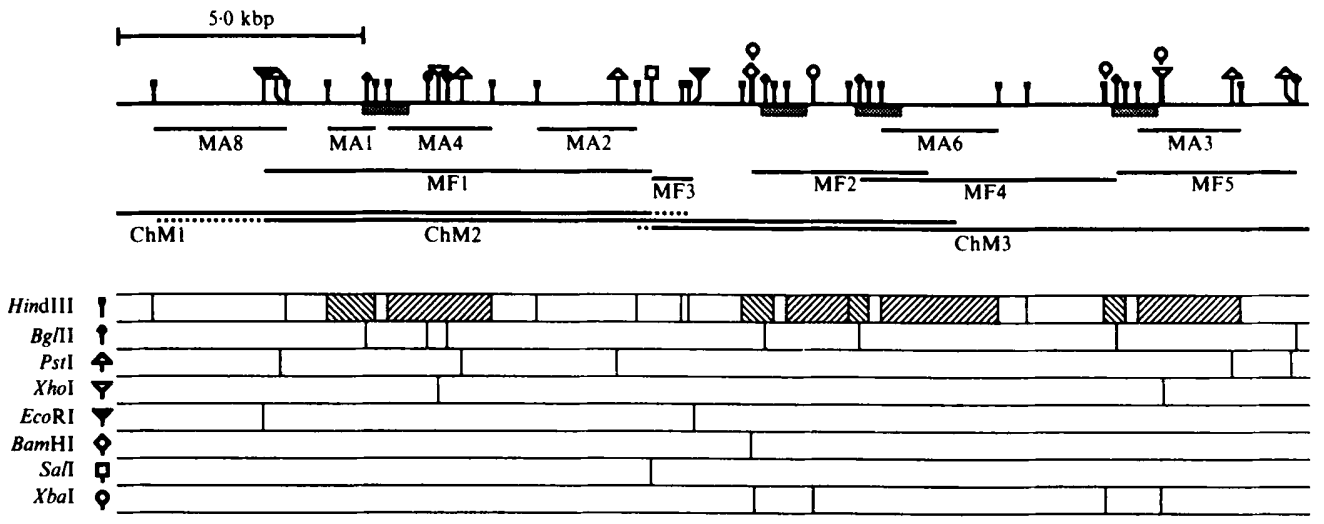

HindIII fragments hybridizing to MAI.

- HindIII fragments hybridizing to MA3, 4 and 6.

- Site of putative IS257-like repeat

Fig. 2. Restriction endonuclease map of cloned DNA. The MA fragments indicated are six of the eight HindIII fragments cloned from ANS46 total cell DNA into pUC9. The MF fragments indicated are five sections subcloned into pUC9 from recombinant Charon 30 phage. The insert DNA sections of three of these phages are shown on the line below.

(pUC9) DNA hybridized with neither probe DNA. Further analysis of the 20 positive clones, by restriction endonuclease digestion and by Southern hybridization, showed that eight different HindIII fragments of the deleted DNA had been cloned. These were named MA1 to 8 in order of increasing size. All eight MA plasmids were used as probes in Southern hybridizations to HindIII-digested ANS46 and ANS62 DNA. None showed any hybridization to ANS62 DNA; all eight hybridized strongly to bands in the ANS46 digest corresponding to the size of their insert, and four showed additional (weaker) hybridization to other bands in the ANS46 digest only.

\section{Screening of phage library}

Plaques of recombinant Charon 30 phage constructed as described were probed with labelled, pooled plasmid DNA of the eight cloned HindIII fragments, and six of those showing hybridization were plaque-purified by the methods of Maniatis et al. (1982). Phage DNA prepared from these recombinants was labelled and used to probe HindIII digests of ANS46 and ANS62 total DNA. All hybridized with bands in the ANS46 digests, and none with ANS62 DNA.

\section{Mapping of overlapping phage clones}

DNA from the six purified Charon 30 recombinants was mapped for HindIII, EcoRI, SalI, $X h o I, X b a I, B a m H I, B g l I I$ and PstI endonuclease sites. The insert DNA of a number of the phage recombinants proved to be nearly the same, and it was found that only $24 \mathrm{~kb}$ of continuous DNA was covered by the inserts, which had an average length of approximately $13 \mathrm{~kb}$. Three representative, overlapping phage inserts (ChM1,2 and 3) are shown on the map of the $24 \mathrm{~kb}$ in Fig. 2. Mapping was accomplished by multiple and partial endonuclease digests, and to facilitate this a number of phage insert fragments were sub-cloned in pUC9 (Fig. 2, MF1 to 5). To identify positively the MA series of HindIII fragments in the mapped region, HindIII digests of the phages were probed in Southern hybridizations with labelled plasmid DNA of each of the eight MA clones. In addition to the expected strong hybridization with a phage insert fragment of identical molecular mass, four of the MA fragments showed weaker hybridization with other fragments, in some cases known MA fragments. Examples of such crosshybridization are shown in Fig. 3. The final pattern of cross-hybridization between the mapped HindIII fragments is shown by shaded areas below the restriction map (Fig. 2). 
(a)

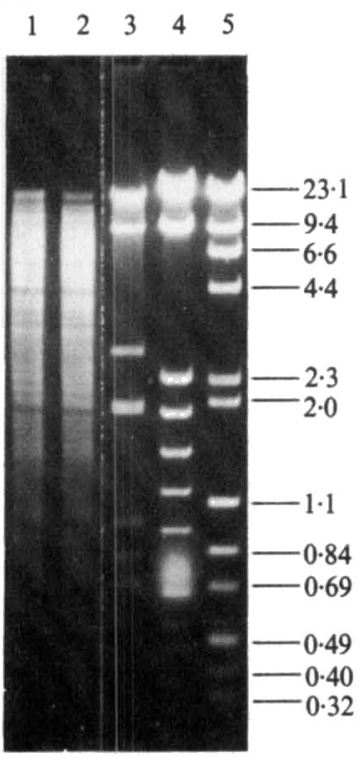

(b)

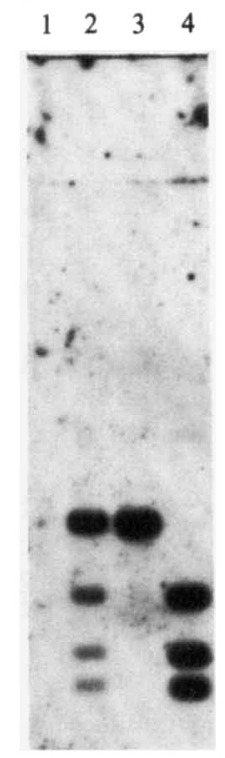

(c)

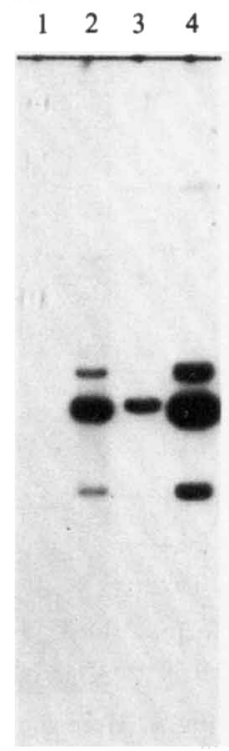

Fig. 3. Cross-hybridization of HindIII fragments. (a) Agarose gel (1.0\%) electrophoresis of recombinant phage and $S$. aureus total DNA after digestion with HindIII. Lanes: 1, ANS62; 2, ANS46; $3, \phi C h M 1 ; 4, \phi C h M 3 ; 5$, molecular mass marker fragments ( $\lambda$, HindIII; pUC9, HindIII/DraI; pUC9, HpaII) with sizes in kb. (b) Autoradiograph of lanes 1-4 from (a) (with lanes 3 and 4 replaced by identical lanes loaded with one-twentieth the amount of DNA) after transfer to nitrocellulose and hybridization with ${ }^{32} \mathrm{P}$-labelled pMA1. (c) Autoradiograph of identical gel to that used in $(b)$ after transfer to nitrocellulose and hybridization with ${ }^{32}$ P-labelled pMA3.

\section{Homology of MA fragments to transduced mec DNA}

In order to confirm the association of the cloned DNA with methicillin resistance in $S$. aureus, total DNA from an independently constructed methicillin resistant/sensitive strain pair was probed with the MA series of eight plasmid clones by Southern hybridization to HindIII digests. The strains used were the wild-type methicillin-resistant isolate C5 (Cohen \& Sweeney, 1970), and strain SC4 and its methicillin-resistant derivative SC4mec, transduced to methicillin resistance using phage $\phi 80$ grown on C5 (Cohen \& Sweeney, 1970). Because these strains contain plasmids (see Table 1) which were found to hybridize to some of the probes, pIC5 and pI524 plasmid DNA was prepared from strains $\mathrm{C} 5$ and SC4, and hybridized in adjacent lanes to HindIII-digested total DNA prepared from the strains. Fig. 4 shows two such hybridizations.

The fragments MA5, MA7 and MA8 showed no detectable homology to these strains. The MA2 fragment $(2.0 \mathrm{~kb})$ showed homology to a $3.0 \mathrm{~kb}$ band in all three strains and to a fragment of the same size in both plasmids. The fragments MA4 $(2.2 \mathrm{~kb})$, MA3 $(2.0 \mathrm{~kb})$ and MA6 $(2.4 \mathrm{~kb})$ all showed homology of varying degree to three fragments $(1.15,2.0$ and $3.8 \mathrm{~kb})$, two of which $(1.15$ and $3.8 \mathrm{~kb})$ were present in the two plasmids. The $2.0 \mathrm{~kb}$ fragment, however, was present only in chromosomal DNA of strains C5 and SC4mec. The intensity of labelling of the three bands, when probed with the three MA fragments, suggested that the $2.0 \mathrm{~kb}$ fragment in $\mathrm{C} 5$ and SC4mec was more than $80 \%$ homologous to the MA3 fragment. The $1.15 \mathrm{~kb}$ plasmid fragment and MA4 were also highly homologous; other homologies were at a lower level (less than $20 \%$ ). Fig. 4(c) illustrates this for MA3.

The fragment MA1 $(1.0 \mathrm{~kb})$ gave a similar hybridization pattern to MA3, demonstrating homology to two fragments present in both plasmids $(0.67$ and $0.73 \mathrm{~kb})$ and to a third fragment of $2.4 \mathrm{~kb}$ present only in strains $\mathrm{C} 5$ and SC4mec (and thus chromosomal). It also showed weak homology to another two fragments present in both plasmids, as shown in Fig. 4(b). 
(a)

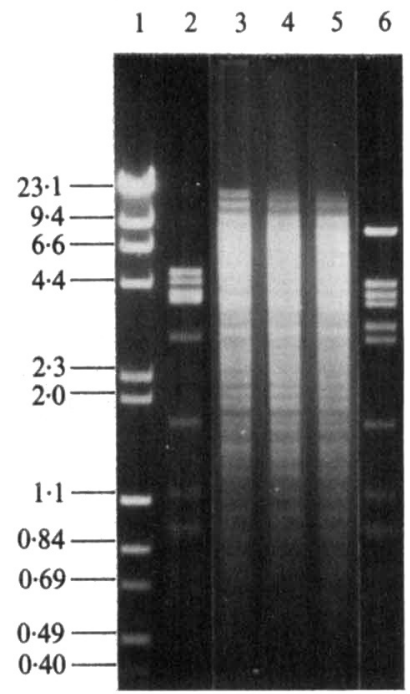

(b)

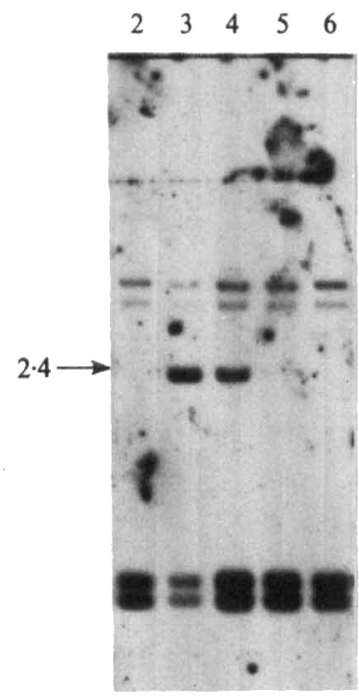

(c)

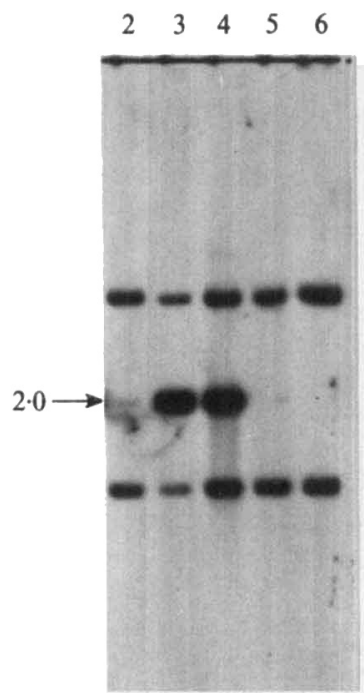

Fig. 4. Homology of MA fragments to transduced mec DNA. (a) Agarose gel (1.0\%) electrophoresis of $S$. aureus plasmid and total DNA after digestion with HindIII. Lanes: 1, molecular mass marker fragments ( $\lambda$, HindIII ; pUC9, HindIII/DraI ; pUC9, HpaII) with sizes in kb; 2, pIC5; 3, C5; 4, SC4mec; $5, \mathrm{SC} 4 ; 6$, pI524. (b) Autoradiograph of lanes $2-6$ from (a) (with lanes 2 and 6 replaced by identical lanes loaded with one-twentieth the amount of DNA) after transfer to nitrocellulose and hybridization with 32P-labelled pMA1. (c) Autoradiograph of identical gel to that used in $(b)$ after transfer to nitrocellulose and hybridization to ${ }^{32} \mathrm{P}$-labelled pMA3. Arrows (with size in $\mathrm{kb}$ ) indicate transduced fragments.

\section{Homology of MA fragments to DNA from step-selected strains}

In order to associate the cloned DNA with mec DNA which may be amplified by increased exposure to methicillin, the cloned fragments MA1, 2, 3, 4 and 6 were used to probe HindIII digests of total DNA prepared from strains ANS46(1000) and C5(1000). Again, those probed with MA1 and MA3 were the only ones to show significant variation in response to the stepselection programme (Fig. 5).

A change shown in all probing experiments was the apparent loss of the plasmid pIC5 from C5 during step-selection, which was confirmed by the loss of mercury resistance. However, probing with the fragment MAl showed the most striking change, with a new fragment appearing in both ANS46(1000) and C5(1000) digests (0.31 and $1.3 \mathrm{~kb}$, Fig. 5). The MA3 fragment hybridized to no new fragments, but did show intensification of the main hybridizing band $(2.0 \mathrm{~kb})$ in both strains, suggesting an increase in the copy number of this fragment.

\section{Homology of pMF5 with pWDB2}

While the work described here was in progress, Beck et al. (1986) described the cloning of a $3.5 \mathrm{~kb} \mathrm{Bg} / \mathrm{II}$ fragment of mec-specific DNA, present in transduced methicillin-resistant strains but not in the methicillin-sensitive transduction recipient. We have compared this BglII fragment with the sub-cloned $B g l$ II fragment MF5, using pWDB2 (a plasmid carrying the BglII fragment isolated by Beck and co-workers). To check for restriction site similarity, a number of different endonucleases were used to cleave both plasmids and the fragments were resolved on a $1.5 \%$ agarose gel (Fig. $6 a$ ). Allowing for the different cloning vectors used, the data show that the MF5 Bg/II fragment is similar, if not identical, to the insert DNA of pWDB2, for HindIII, $P s t I$ and $X h o I$ sites. Small increases in fragment sizes from pMF5 are accounted for by the multiple cloning site of pUC9, as pMF5 was made by inserting the $3.5 \mathrm{~kb} \mathrm{BglII}$ fragment into the pUC9 BamHI site. In addition, separate digests of pMF5 and pWDB2 were electrophoresed on a $1 \%$ gel, blotted to nitrocellulose and probed with ${ }^{32}$ P-labelled pMF5 DNA (Fig. $6 b, c$ ). These results confirm that the insert DNA of the two plasmids has a high degree of sequence homology. 
(a)

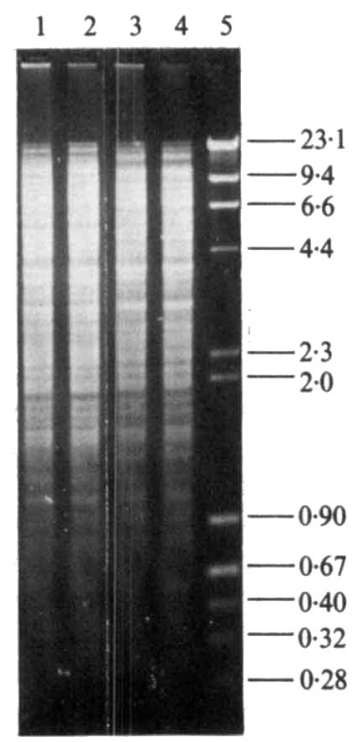

(b)

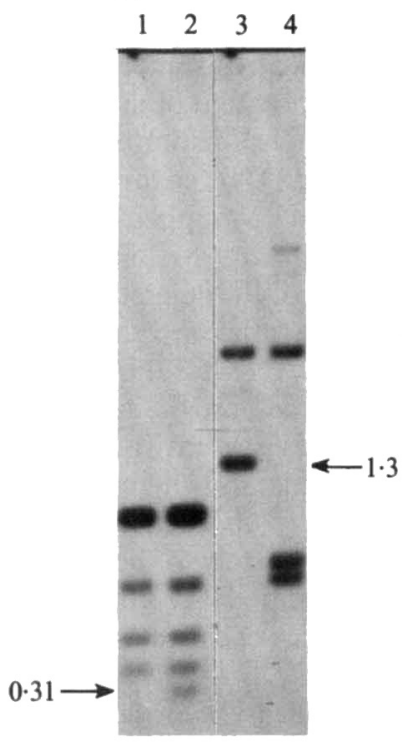

(c)

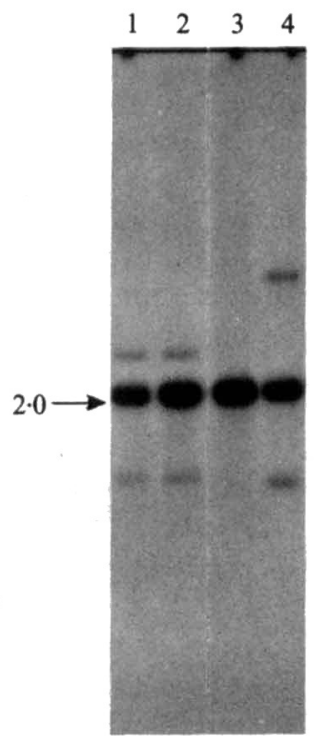

Fig. 5. Homology of MA fragments to DNA from step-selected strains. (a) Agarose gel $(1 \cdot 2 \%)$ electrophoresis of $S$. aureus total DNA after digestion with HindIII. Lanes: 1, ANS46; 2, ANS46(1000); 3, C5(1000); 4, C5; 5, molecular mass marker fragments ( $\lambda$, HindIII; pBR322, AluI) with sizes in $\mathrm{kb}$. (b) Autoradiograph of lanes 1-4 from (a) after transfer to nitrocellulose and hybridization to ${ }^{32} \mathrm{P}$-labelled pMA1. (c) Autoradiograph of identical gel to that used in $(b)$ after transfer to nicrocellulose and hybridization to ${ }^{32} \mathrm{P}$-labelled pMA3. Arrows (with size in $\mathrm{kb}$ ) indicate new or amplified fragments present in step-selected strains.

(a)

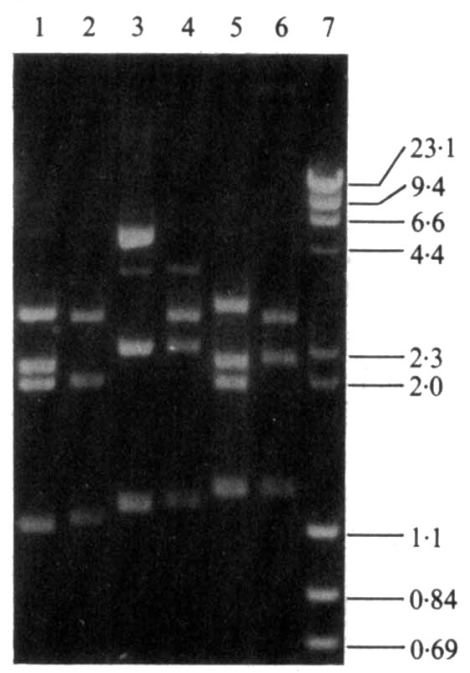

(b)

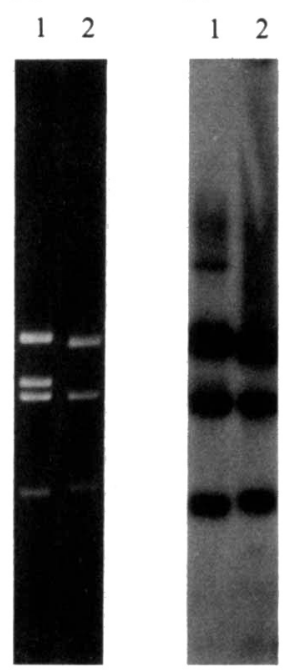

Fig. 6. Comparison of pMF5 with pWDB2. (a) Agarose gel (1.5\%) electrophoresis of endonucleasedigested pWDB2 and pMF5 DNA. Lanes: 1, pWDB2, BglII/HindIII; 2, pMF5, EcoRI/HindIII; 3, pWDB2, BglII/XhoI ; 4, pMF5, EcoRI/SalI/XhoI ; 5, pWDB2, BglII/PstI; 6, pMF5, EcoRI/PstI; 7, molecular mass marker fragments ( $\lambda$, HindIII; pUC9, HindIII/DraI). (b) Repeat of lanes 1 and 2 in $(a)$ on a $1.0 \%$ agarose gel. (c) Autoradiograph of $(b)$ after transfer to nitrocellulose and hybridization to ${ }^{32} \mathrm{P}$ labelled pMF5. 


\section{DISCUSSION}

In this study we have cloned and mapped $24 \mathrm{~kb}$ of DNA which when deleted from the clinical isolate ANS46 correlates with the loss of resistance to mercury, cadmium, tetracycline and methicillin. This does not appear to be the extent of the total deletion of DNA, since summation of fragment sizes seen in competitive hybridizations of ANS46 and ANS62 suggests that at least $35 \mathrm{~kb}$ is deleted. None of the deleted DNA so far mapped is homologous with sequences in the sensitive strain, indicating that the $24 \mathrm{~kb}$ mapped does not carry an end of the deletion. The proximity of the two unmapped MA fragments, MA5 and MA7, to this $24 \mathrm{~kb}$ is still unknown. It cannot be determined whether the whole of the deleted DNA is a continuous sequence, although this appears to be the case for the $24 \mathrm{~kb}$ so far cloned as fragment sizes seen in XhoI, EcoRI/XhoI, EcoRI, PstI, XbaI and BglII digests of ANS46 DNA, when probed both by the competitive procedure and with various fragment probes, are the same as the homologous, cloned fragments.

The map of the cloned DNA reveals several interesting features. The pattern of crosshybridization between HindIII fragments shown in Fig. 2 reveals that MAl and the three fragments hybridizing with it are located in each case immediately to the left of a $0.25 \mathrm{~kb}$ HindIII fragment, which in turn is immediately to the left of a HindIII fragment hybridizing to MA3, 4 or 6. In addition, a BglII site is located $0.18 \mathrm{~kb}$ to the left of the $0.25 \mathrm{~kb}$ HindIII fragment in all four cases. This points to the presence of a direct repeat sequence at four places in the $24 \mathrm{~kb}$ of cloned DNA.

This repeat sequence shows endonuclease site identity to the putative insertion sequence IS257 (Lyon \& Skurray, 1987). Furthermore, the hybridization of MA1, 3, 4 and 6 to HindIII fragments of pI524 (Fig. 4) containing part of two directly repeated IS257-like sequences flanking the mercury resistance determinant on this plasmid (M. T. Gillespie \& R. A. Skurray, personal communication), also indicates similarity of the repeat and IS257. Indeed, the restriction endonuclease map of the $7 \mathrm{~kb}$ sequence lying between the first and second repeats on the left end of the mapped $24 \mathrm{~kb}$ (Fig. 2) resembles that of the mercury-resistance determinants (merA merB) of pI524 (Gillespie et al., 1986a), except for the most leftward $2 \mathrm{~kb}$.

Likewise, the HindIII and $X b a I$ restriction endonuclease map of the 'inter-repeat' region covered by the $5.2 \mathrm{~kb} \mathrm{BglII}$ fragment MF4 is the same as that of the integrated tetracyclineresistance plasmid pT181 of $S$. aureus (Gillespie et al., 1986 b; K han \& Novick, 1983). Thus, the four repeats identified may represent flanking or otherwise associated sequences for transposable resistance genes, although transposition of mercury and tetracycline resistance has not so far been demonstrated in $S$. aureus. Repeat sequences may also provide the basis for clonal variation (heterogeneity) of the expression of methicillin resistance in staphylococci (Matthews \& Stewart, 1984).

When looking for the possible location of a methicillin-resistance gene, the strong association of methicillin resistance with the HindIII fragments MA1 and MA3 is suggestive. This association is demonstrated both in the homology of these fragments with HindIII fragments transduced into the strain SC4 (concomitantly with methicillin resistance) from the MRSA strain C5 (Fig. 4), and in their homology with HindIII fragments created or amplified when the MRSA strains ANS46 and C5 are step-selected to high levels of methicillin resistance by serial subculture in increasing concentrations of the drug (Fig. 5). Thus MA3 shows homology to a transduced mec-associated fragment the same size as MA3 (Fig. 4), and shows an increase in copy number in response to methicillin step-selection (Fig. 5). By contrast, MA1 shows homology to new fragments differing in size to MAl in transduced and step-selected strains. These results suggest that the homology of the MAl fragment to mec-specific DNA is only by virtue of the IS257-like repeat DNA which it carries, and that MA3 and its associated IS257-like repeat constitute true mec-specific DNA. The homology of the MF5 fragment (which contains MA3) with the $3.5 \mathrm{~kb}$ mec-specific BglII fragment of Beck et al. (1986) indicates that these workers, using transduction to fragment the cell genome, isolated the same mec-associated DNA as that described here.

It will be of interest to determine whether MF5 and the $3.5 \mathrm{~kb} \mathrm{BglII}$ fragment of Beck et al. (1986) are homologous to the 14 kb DNA fragment encoding PBP2' isolated by Matsuhashi et al. (1986); PBP2' has low affinity for $\beta$-lactam antibiotics generally, and is believed to provide the basis for intrinsic resistance of staphylococci to these agents. 
However, the appearance of new bands in the probing of ANS46(1000) and C5(1000) chromosomal DNA HindIII digests (Fig. 5) suggests more than the mec-specific nature of MA3. Given that the intensity of the main chromosomal band hybridizing to MA3 roughly doubles in each case, we postulate that resistance amplification is accompanied by a duplication of a section of the mapped DNA containing MA3, beginning immediately to the left of the IS257like repeat partially contained in MA3 (and thereby creating new HindIII fragments of different size hybridizing to MAl) and extending an undefined distance to the right on the map of Fig. 2 . The presence of such a duplication has been confirmed in ANS46 and is currently being characterized.

We thank Helen Waldron for assistance in the isolation of ANS62, and Sidney Cohen, Wolfgang Beck, Brigitte Berger-Bachi and Ken Harvey for strains of $S$. aureus. We also thank Matthew Gillespie and Ron Skurray for drawing our attention to the likely presence of the mer locus in the cloned sequences. This work was supported by the National Health and Medical Research Council of Australia.

\section{REFERENCES}

BeCK, W. D., Berger-BACHI, B. \& Kayser, F. H. (1986). Additional DNA in methicillin-resistant Staphylococcus aureus and molecular cloning of mecspecific DNA. Journal of Bacteriology 165, 373-378.

BERGER-BACHI, B. \& KoHLER, M. L. (1983). A novel site on the chromosome of Staphylococcus aureus influencing the level of methicillin resistance: genetic mapping. FEMS Microbiology Letters 20, 305-309.

COHEN, S. \& SWEeney, H. M. (1970). Transduction of methicillin resistance in Staphylococcus aureus dependent on an unusual specificity of the recipient strain. Journal of Bacteriology 104, 1158-1167.

Gillespie, M. T., May, J. W. \& Skurray, R. A. (1984). Antibiotic susceptibilities and plasmid profiles of nosocomial methicillin-resistant Staphylococcus aureus: a retrospective study. Journal of Medical Microbiology 17, 295-310.

Gillespie, M. T., May, J. W. \& Skurray, R. A. (1986a). Plasmid-encoded resistance to acriflavine and quaternary ammonium compounds in methicillin-resistant Staphylococcus aureus. FEMS Microbiology Letters 34, 47-51.

Gillespie, M. T., May, J. W. \& Skurray, R. A. $(1986 b)$. Detection of an integrated tetracycline resistance plasmid in the chromosome of methicillinresistant Staphylococcus aureus. Journal of General Microbiology 132, 1723-1728.

Heneine, N. \& Stewart, P. R. (1986). Physiological determination of methicillin resistance in Staphylococcus aureus: comparison of clinical and genetically derived isolates. Journal of Antimicrobial Chemotherapy 17, 705-715.

Johnson, D. A., Gautsch, J. W., Sportsman, J. R. \& ELDER, J. H. (1984). Improved technique involving nonfat dry milk for analysis of proteins and nucleic acids transferred to nitrocellulose. Gene Analytical Techniques 1, 3-8.

Khan, S. A. \& Novick, R. P. (1983). Complete nucleotide sequence of pT181, a tetracycline-resistance plasmid from Staphylococcus aureus. Plasmid 10, 251-259.

Lyon, B. R. \& SKURRAY, R. A. (1987). Antimicrobial resistance of Staphylococcus aureus: genetic basis. Microbiological Reviews 51, 88-134.

Maniatis, T., Fritsch, E. F. \& Sambrook, J. (1982). Molecular Cloning: a Laboratory Manual. Cold
Spring Harbor, NY: Cold Spring Harbor Laboratory.

Matsuhashi, M., Dong Song, M., Ishino, F., WachI, M., DoI, M., INOUe, M., Ubukata, K., Yamashita, N. \& KonNo, M. (1986). Molecular cloning of the gene of a penicillin-binding protein supposed to cause high resistance to $\beta$-lactam antibiotics in Staphylococcus aureus. Journal of Bacteriology 167, 975-980.

Matthews, P. R. \& Stewart, P. R. (1984). Resistance heterogeneity in methicillin resistant Staphylococcus aureus. FEMS Microbiology Letters 22, 161-166.

NiLsson, S. V. \& MAGnusson, G. (1982). Sealing of gaps in duplex DNA by T4 DNA ligase. Nucleic Acids Research 10, 1425-1437.

ReEd, K. C. \& MANN, D. A. (1985). Rapid transfer of DNA from agarose gels to nylon membranes. Nucleic Acids Research 13, 7203-7221.

ReYNolds, P. E. \& Fuller, C. (1986). Methicillinresistant strains of Staphylococcus aureus: presence of identical additional penicillin-binding protein in all strains examined. FEMS Microbiology Letters 33, 251-254.

Rimm, D. L., Horness, D., Kucera, J. \& Blattner, F. R. (1980). Construction of coliphage lambda Charon vectors with BamHI cloning sites. Gene 12, 301-309.

Shalita, Z., Murphy, E. \& Novick, R. P. (1980). Penicillinase plasmids of Staphylococcus aureus: structural and evolutionary relationships. Plasmid 3, 291-311.

SOUTHERN, E. M. (1975). Detection of specific sequences among DNA fragments separated by gel electrophoresis. Journal of Molecular Biology 98, 503-517.

StEwart, G. C. \& Rosenblum, E. D. (1980). Genetic behaviour of the methicillin resistance determinant in Staphylococcus aureus. Journal of Bacteriology 144, 1200-1202.

Stewart, P. R., Waldron, H. G., Lee, J. S. \& MATtHEWS, P. R. (1985). Molecular relationships among serogroup B bacteriophages of Staphylococcus aureus. Journal of Virology 55, 111-116.

VIEIRA, J. \& Messing, J. (1982). The pUC plasmids, an M13mp7-derived system for insertion mutagenesis and sequencing with synthetic universal primers. Gene 19, 259-268. 